\title{
Kadar Serat dan Kadar Air serta Penampakan Fisik Produk Pascapanen Daun Caisim (Brassica juncea L.) yang Ditanam pada Media dengan Penambahan Pupuk Organik Hayati Cair dan Pupuk Anorganik
}

\author{
Dwi Winarsih, Erma Prihastanti, dan Endang Saptiningsih \\ Laboratorium Biologi Struktur dan Fungsi Tumbuhan Jurusan Biologi FSM Undip
}

\begin{abstract}
Caisim (Brassica juncea L.) is one of vegetable commodities that has a high commercial value. Many people like it because it has a good taste and it contains several kinds of vitamin and mineral that good for health. This research aims to know the influence of liquid bio organic fertilizer and inorganic fertilizer addition to post harvest product caisim leaf and know the best combination of fertilizer for post harvest product caisim leafquality. Data analysis used is Analysis of Variance (ANOVA) and then continued by test significant different used Duncan Multiple Range Test (DMRT) 95\%. The caisim plant that have been harvested then being observed on its fiber content, water content, and physical appearance. The result showed thatthe addition of liquid bio organic fertilizer and inorganic fertilizer has not influence for water content and physical appearance of caisim leaf, but it has an influence on fiber content. Treatment with basic media with the addition of $1 \mathrm{~mL}+2,17 \mathrm{~g}$ NPK is the best treatment to increase fiber content of caisim leaf Tosakan variety.
\end{abstract}

Keywords: liquid bio organic fertilizer, caisim, quality of post harvest product

\begin{abstract}
Abstrak
Tanaman caisim (Brassica juncea L.)merupakan komoditas sayuran yang memiliki nilai komersial tinggi.Banyak masyarakat menyukai sayuran ini karena caisim memilikirasa yang lezat serta mengandung vitamin dan mineral yang baik untuk kesehatan.Penelitian ini bertujuan untuk mengetahui pengaruh penambahan pupuk organik hayati cair dan pupuk anorganik terhadap kualitas produk pascapanen daun caisim serta mengetahui kombinasi pupuk yang paling baik terhadap kualitas produk pascapanen daun caisim. Analisis data yang digunakan adalah Analisis of Variance (ANOVA) yang dilanjutkan dengan uji beda nyata Duncan Multiple Range Test (DMRT) pada taraf signifikasi 95\%.Tanaman caisim (Brassica juncea L.) yang dipanen langsung dilakukan pengamatan pada kadar serat, kadar air dan penampakan fisik. Hasil penelitian menunjukkan bahwapenambahan pupuk organik hayati cair dan pupuk anorganik tidak berpengaruh terhadap kadar air dan penampakan fisik daun caisim, namun berpengaruh terhadap kadar serat daun. Perlakuan pada media dasardengan penambahan $1 \mathrm{~mL}$ POHC dan 2,17 g NPK mampu meningkatkan kadar serat daun caisim varietas Tosakan.
\end{abstract}

Kata kunci: pupuk organik hayati cair, caisim, kualitas produk pascapanen

\section{PENDAHULUAN}

Tanaman caisim (Brassica juncea L.) merupakan salah satu sayuran berdaun segar yang disukai masyarakat. Menurut Fransisca (2009), kebutuhan tanaman caisim setiap tahun mengalami peningkatan sekitar $7 \%$ sampai $14 \%$.Peningkatan caisim disebabkan karena bertambahnya populasi dan kesadaran manusia akan pentingnya sayuran bagi tubuh. Permintaan caisim yang tinggi mendorong petani caisim untuk meningkatkan kualitas hasil produksi, seperti dalam pemeliharaan dan pembudidayaannya.Budidaya caisim yang optimal akan menentukan produktivitas dan kualitas tanaman caisim. Kualitas produk caisim yang optimal akan menentukan nilai jual caisim. Kualitas produk sayuran segar dilihat dari kesegaran dan kerenyahan yang meliputi kadar air dan tekstur, nilai gizi, serta penampakan fisik. Penampakan fisik meliputi ukuran daun, bentuk daun (terdapat bercak dan lubang pada daun), dan warna daun pada sayuran (Nirwana, 2009).

Tanaman caisim yang digunakan yaitu caisim varietas Tosakan. Ciri caisim varietas Tosakan bila dibandingkan dengan caisim varietas 
lain yaitu memiliki warna daun hijau muda, selain itu memiliki rasa yang tidak pahit, sehingga banyak digemari masyarakat(East West Seed Indonesia, 2006). Caisim mengandung banyak vitamin dan mineral yang baik untuk kesehatan tubuh. Menurut Rukmana (2007), komposisi zatzat makanan yang terkandung dalam caisim antara lain: Vitamin A, B, C, Ca, Protein, Karbohidrat, Lemak, Fe, dan P.

Kondisi iklim yang dikehendaki untuk pertumbuhan caisim adalah daerah yang mempunyai suhu malam hari $15,6^{\circ} \mathrm{C}$ dan siang harinya $21,1^{\circ} \mathrm{C}$ serta penyinaran matahari antara 10-13 jam perhari. Tanaman caisim dapat tumbuh dengan baik pada suhu $27^{\circ} \mathrm{C}-32^{\circ} \mathrm{C}$ (Rukmana, 2007).

Tanah yang cocok untuk budidaya caisim adalah tanah yang gembur, subur dan banyak mengandung humus.Derajat keasaman $(\mathrm{pH})$ yang optimum untuk pertumbuhannya adalah antara $\mathrm{pH}$ 6-7.Jenis tanah yang paling baik untuk pertumbuhan caisim adalah jenis tanah lempung berpasir seperti tanah andosol yaitu tanah yang berasal dari abu vulkanik (Rukmana, 2007).

Caisim umumnya dibudidayakan menggunakan pupuk anorganik dan pupuk organik, namun beberapa petani sudah mulai membudidayakan secara organik.Pemberian pupuk organik sebagai pupuk tunggal tidak dapat meningkatkan kualitas tanaman caisim secara cepat, sebab proses dekomposisi bahan organik berjalan cukup lambat. Pupuk anorganik dapat menghasilkan varietas yang unggul dan berproduksi tinggi. Kelebihan pupuk anorganik yaitu dapat diberikan dengan takaran yang tepat sesuai dengan kebutuhan tanama. Selain itu unsur haranya mudah larut dalam air sehingga unsur hara yang terkandung mudah tersedia bagi tanaman (Setyamidjaja, 1995).

Pemakaian pupuk anorganik dalam waktu lama akan menimbulkan permasalahan pada lahan pertanian. Bahaya penggunaan pupuk anorganik mulai dirasakan oleh masyarakat khususnya petani. Para petani mulai meninggalkan pupuk anorganik dan melirik cara pertanian alamiah yaitu pertanian organik modern.Razak dkk., (2005) menyatakan penambahan pupuk organik dan pupuk anorganik akan saling melengkapi hara yang diperlukan tanaman, sehingga dapat menunjang kualitas produk tanaman. Kualitas produk pascapanenseperti kadar serat dan air serta penampakan fisik pada daun caisim yang ditanam pada media dengan penambahan pupuk organik hayati cair dan pupuk anorganik belum banyak diketahui, oleh karena itu penulis tertarik untuk mengkajinya lebih lanjut.

\section{BAHAN DAN METODE}

Penelitian ini dilaksanakan di rumah kaca Balai Besar Penelitian dan Pengembangan Bioteknologi dan Sumberdaya Genetika Pertanian, serta Balai Besar Penanganan Pascapanen, Cimanggu Bogor pada bulan November Desember 2010. Bahan yang digunakan yaitudolomit, kompos, pupuk anorganik yaitu pupuk NPK (Urea, SP-36, dan $\mathrm{KCl}$ ), pupuk organik hayati cair yang berasal dari ekstrak kompos yang diberi beberapa inokulan yaitu Klebsiela planticola, Pseudomonas pseudomallei, dan Alakaligenuseutrophus, aseton 85\%, caisim varietas Tosakan, air, $\mathrm{H}_{2} \mathrm{SO}_{4}, \mathrm{NaOH}$.Alat yang digunakan meliputi kromameter minolta, oven, botol timbang, kertas saring, gelas piala, corong, bolpoint, buku, kertas millimeter blok, plastik kantong besar, label, kamera, dan polybag.

Tanaman caisim ditanam pada polybag dengan berbagai kombinasi pupuk organik hayati cair dan pupuk anorganik. Pupuk diberikan sebelum benih caisim ditanam pada polybag. Setelah benih caisim ditanam pada polybag dilakukan pemeliharaan dengan melakukan penyiangan setiap hari. Pemanenan dilakukan saat caisim berumur 28 hari. Pemanenan dilakukan pada waktu pagi hari jam 08.00. Caisim yang telah dipanen kemudian dibersihkan dari kotoran. Setelah dibersihkan daun caisim diukur sesuai dengan parameter yang telah ditentukan. Parameter yang diamati yaitu kadar serat daun, kadar air daun, lubang dan bercak daun, warna daun, dan luas penguningan daun.

Uji statistik yang digunakan pada penelitian ini adalah Analisis Varians (ANOVA) dengan Rancangan Acak Lengkap (RAL) pada tingkat kepercayaan $95 \%$. 


\section{HASIL DAN PEMBAHASAN}

Tabel 1. Rerata kadar seratdaun yang diberi berbagai perlakuan pupuk organik hayati cair dan pupuk anorganik pada minggu ke -4 setelah tanam.

\begin{tabular}{ll}
\hline Perlakuan & $\begin{array}{l}\text { Serat daun } \\
(\%)\end{array}$ \\
\hline $\begin{array}{l}\text { P0 (media dasar berupa tanah }+ \\
\text { kompos) }\end{array}$ & $0,90^{\mathrm{c}}$ \\
\hline P1 (media dasar+4,35 g NPK) & $0,96^{\mathrm{bc}}$ \\
\hline P2 (media dasar+2 mL POHC+4,35 g & $0,98^{\mathrm{bc}}$ \\
NPK) & \\
\hline P3 (media dasar+2 mL POHC+2,17g & $1,07^{\mathrm{bc}}$ \\
NPK) & \\
\hline P4 (media dasar+2 mL POHC+1,07 g & $1,03^{\mathrm{bc}}$ \\
NPK) & \\
\hline P5 (media dasar+1 mL POHC $+4,35 \mathrm{~g}$ & $1,18^{\mathrm{bc}}$ \\
NPK) & \\
\hline P6 (media dasar+1 mL POHC+2,17g & $1,64^{\mathrm{a}}$ \\
NPK) & \\
\hline P7 (media dasar+1 mL POHC+1,07 g & $1,44^{\mathrm{ab}}$ \\
NPK) & \\
\hline
\end{tabular}

*angka-angka yang diikuti oleh huruf yang sama dalam satu kolom tidak menunjukkan perbedaan yang nyata menurut DMRT 95\%.

Penambahan $1 \mathrm{~mL}$ pupuk organik hayati cair dan 2,17 g NPK menyebabkan kandungan serat daun caisim cenderung paling tinggi. Hal tersebut dikarenakan bakteri yang terkandung dalam pupuk organik hayati cair yaitu bakteri penambat nitrogen seperti Pseudomonas dan Klebsiella menyebabkan kandungan nitrogen tinggi. Menurut James dan Olivares (1997), bahwa Pseudomonas dan Klebsiella terbukti mampu meningkatkan penambatan $\mathrm{N}_{2}$ pada tanaman padi sehingga meskipun jumlah pupuk anorganik dikurangi, tanaman tidak kekurangan $\mathrm{N}$.

Berdasarkan tabel di atas pemberian pupuk organik hayati cair yang semakin tinggi menghasilkan serat daun yang lebih rendah.Pemberian pupuk organik hayati cair yang semakin meningkat menyebabkan tingginya mikroorganisme di sekitar akar.Hal ini menyebabkan terjadinya peningkatan aktivitas mikroorganisme untuk melakukan fiksasi nitrogen.Tujuan fiksasi nitrogen yaitu pengikatan nitrogen oleh mikroorganisme yang mengubah bentuk $\mathrm{N}_{2}$ dari udara menjadi ammonium $\left(\mathrm{NH}_{4}{ }^{+}\right)$ yang tersedia bagi tanaman.Bakteri membutuhkan karbohidrat dan elektron dalam fiksasi $\mathrm{N}$ sebagai energi dan mereduksi nitrogen menjadi senyawa ammonium.Ammonium nantinya akan diubah menjadi senyawa yang dapat dimanfaatkan oleh tanaman. Karbohidrat dan elektron yang digunakan oleh bakteri untuk fiksasi $\mathrm{N}$ berasal dari hasil fotosintesis, padahal hasil fotosintesis tersebut akan digunakan untuk pembentukan serat. Antara fiksasi nitrogen oleh mikroorganisme dan pembentukan serat terjadi persaingan untuk samasama mengambil produk fotosintesis(Hanafiah, 2007).

Unsur hara yang tinggi, terutama kandungan nitrogen menyebabkan terjadinya peningkatan hasil metabolisme, seperti pembesaran sel dan penebalan dinding sel. Hal tersebut akan mengakibatkan sistem jaringan dasar dan sistem berkas pengangkut pada daun caisim lebih banyak (Gardner et al., 1991). Sistem jaringan dasar dan sistem jaringan pengangkut pada umumnya berasal dari polisakarida non pati yang meliputi selulosa, hemiselulosa, dan pektinyang membentuk serat (Pantastico, 1989).

Perlakuan P0 yaitu media dasar berupa tanah dan kompos tanpa penambahan pupuk cenderung mempunyai kadar serat paling rendah. Hal tersebut disebabkan tidak adanya pupuk organik hayati cair dan pupuk anorganik yang dapat menghasilkan nitrogen, sedangkan kandungan nitrogen yang terkandung pada media dasar hanya sedikit yaitu 0,90 per $100 \mathrm{~g}$.

Tabel 2. Rerata kadar air yang diberi berbagai perlakuan pupuk organik hayati cair dan pupuk anorganik pada minggu ke -4 setelah tanam.

\begin{tabular}{ll}
\hline Perlakuan & $\begin{array}{l}\text { Kadar air } \\
(\%)\end{array}$ \\
\hline $\begin{array}{l}\text { P0 (media dasar berupa tanah }+ \\
\text { kompos) }\end{array}$ & 90,54 \\
\hline P1 (media dasar+4,35 g NPK) & 89,91 \\
\hline P2 (media dasar+2 mL POHC+4,35 g & 89,32 \\
NPK) & \\
\hline P3 (media dasar+2 mL POHC+2,17 g & 89,25 \\
NPK) & \\
\hline P4 (media dasar+2 mL POHC+1,07 g & 91,71 \\
NPK) & \\
\hline
\end{tabular}




\begin{tabular}{ll}
\hline P5 (media dasar+1 mL POHC +4,35 g & 89,39 \\
NPK) & \\
\hline P6 (media dasar+1 mL POHC+2,17 g & 90,71 \\
NPK) & \\
\hline P7 (media dasar+1 mL POHC+1,07 g & 90,78 \\
NPK) & \\
\hline
\end{tabular}

Berdasarkan pengukuran kadar air pada daun caisim yang ditanam pada media tanah dan kompos dengan penambahan pupuk organik hayati cair dan pupuk anorganik tidak menunjukkan adanya perbedaan secara signifikan. Hal tersebut dikarenakan semua kadar air yang terkandung pada daun caisim hampir sama yaitu berkisar antara $89,25 \%$ sampai dengan $91,71 \%$. Meski tidak terdapat perbedaan, namun pada perlakuan P4 yaitu dengan penambahan $2 \mathrm{~mL}$ POHC dan 1,07 g NPK mempunyai kecenderungan kadar air lebih tinggi dibandingkan dengan perlakuan lainnya.

Utami (2010), menyatakan bahwa kadar air yang terkandung pada daun caisim umunya berkisar 90\% sampai 93\%. Hal ini sesuai kadar air yang diperoleh dengan penambahan $2 \mathrm{~mL}$ POHC dan 1,07 g NPK yaitu $91,71 \%$. Menurut penelitian Fajriani (2011), penambahan $2 \mathrm{~mL}$ pupuk organik hayati cair dan 1,07 g NPK pada tanaman caisim dapat menghasilkan jumlah akar yang lebih banyak dan lebih panjang. Hal tersebut disebabkan mikroorganisme yang terkandung pada pupuk organik hayati cair yang berperan untuk mendekomposisi unsur hara dan mampu menyerap unsur hara serta air ke tempat yang lebih jauh. Penyerapan air dapat terjadi dengan perpanjangan akar ke tempat baru yang terdapat sumber air. Akar merupakan organ vegetatif yang dapat memasok air, mineral, dan unsur hara yang penting untuk pertumbuhan tanaman.

Berdasarkan tabel di atas penambahan pupuk anorganik yang semakin meningkat akan mengurangi kadar air daun caisim. Hal ini sesuai dengan pernyataan Hanafiah (2007), bahwa pertumbuhan akar tanaman akan terhambat jika unsur hara dalam tanah terlalu banyak. Pengurangan pupuk anorganik memberikan dampak positif bagi pertumbuhan tanaman, terutama oleh akar. Penggunaan pupuk anorganik yang tinggi akan membuat $\mathrm{pH}$ tanah semakin asam dan menekanpertumbuhan mikroorganisme tanah sehingga proses dekomposisi bahan organik pun terhambat (Martynuk dan Wagner, 1978).

Nitrogen dapat meningkatkan perbandingan protoplasma terhadap bahan dinding selyang dapat menyebabkan bertambah besarnya ukursel yang tipis, sehingga banyak diisi oleh air. Penyerapan air yang lebih banyak menyebabkan tanaman dalam keadaan segar. Tanaman yang mengandung banyak air maka kondisi sayuran akan jauh lebih segar lebih lama. Para konsumen lebih menyukai sayuran yang segar dengan kadar air yang tinggi (Winarno, 2002).

Tabel 3. Rerata bercak dan lubang pada daun caisim yang diberi berbagai perlakuan pupuk organik hayati cair dan pupuk anorganik pada minggu ke -4 setelah tanam.

\begin{tabular}{|c|c|c|}
\hline Perlakuan & $\begin{array}{l}\text { Bercak } \\
\text { Daun }\end{array}$ & $\begin{array}{l}\text { Lubang } \\
\text { daun }\end{array}$ \\
\hline $\begin{array}{l}\text { P0 (media dasar berupa tanah } \\
+ \text { kompos) }\end{array}$ & 4,5 & 0,3 \\
\hline $\mathrm{P} 1$ (media dasar+4,35 g NPK) & 3,0 & 2,67 \\
\hline $\begin{array}{l}\text { P2 (media dasar+2 mL } \\
\text { POHC }+4,35 \mathrm{~g} \text { NPK) }\end{array}$ & 1,75 & 0 \\
\hline $\begin{array}{l}\text { P3 (media dasar+2 mL } \\
\text { POHC }+2,17 \mathrm{~g} \mathrm{NPK})\end{array}$ & 3 & 1,83 \\
\hline $\begin{array}{l}\mathrm{P} 4 \text { (media dasar+2 mL } \\
\mathrm{POHC}+1,07 \mathrm{~g} \text { NPK) }\end{array}$ & 1,5 & 2 \\
\hline $\begin{array}{l}\text { P5 (media dasar+1 } \mathrm{mL} \text { POHC } \\
+4,35 \mathrm{~g} \text { NPK) }\end{array}$ & 2 & 2 \\
\hline $\begin{array}{l}\text { P6 (media dasar+1 mL } \\
\text { POHC+2,17 g NPK) }\end{array}$ & 1 & 1 \\
\hline $\begin{array}{l}\text { P7 (media dasar+1 mL } \\
\text { POHC }+1,07 \mathrm{~g} \mathrm{NPK})\end{array}$ & 1,3 & 0 \\
\hline
\end{tabular}

Penambahan berbagai kombinasi pupuk organik hayati cair dan anorganik tidak berpengaruh terhadap bercak dan lubang daun. Banyak faktor yang mempengaruhi lubang dan bercak daun sehingga menyebabkan tidak berbeda secara signifikan.Faktor yang mempengaruhi terjadinya lubang dan bercak daun, yaitu:kandungan hara, suhu, kadar air, intensitas dan lama hujan, kelembaban, angin (Purna, 2010).

Bercak daun merupakan salah satu penyakit yang disebabkan oleh mikroorganisme seperti bakteri dan jamur.Bercak daun dapat menyebabkan penurunan kualitas daun caisim (Margiyanto, 2007).Adanya bakteri dan jamur 
pada daun caisim juga dapat disebabkan oleh angin.Angin dapat menularkan mikroorganisme ke daun yang lain (Afriza, 2009).

Bercak yang timbul pada daun sawi berwarna coklat muda dengan bentuk yang tidak beraturan, kemudian semakin membesar dan meluas berwarna coklat tua.Sekitar bercak terdapat warna kekuningan.Gejala ini biasanya ditimbulkan oleh jamur dari kelas Deutromycetes (Elviera, 1995). Parenkim palisade merupakan jaringan daun yang biasanya dimasuki oleh mikroorganisme. Jaringan ini berdinding tipis sehingga mudah sekali ditembus oleh mikroorganisme. Parenkim palisade adalah jaringan fotosintesis yang menghasilkan glukosa dan oksigen.Mikroorganisme mengambil glukosa dan oksigen dari parenkim palisade untuk bahan metabolisme. Jaringan yang ditembus mikroorganisme berangsur-angsur mulai menular ke jaringan daun yang lain sehingga daun mengalami perubahan warna dan mati (Elviera, 1995).

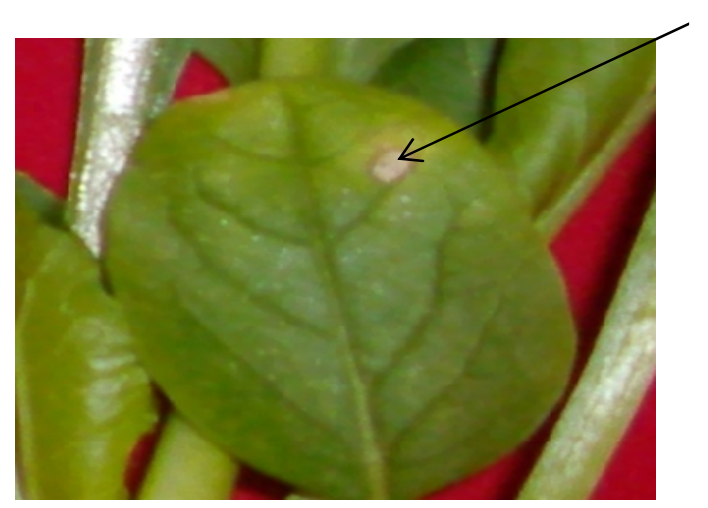

Keterangan:

1. Bercak Daun

Caisim merupakan tanaman sukulen, kadar air yang terkandung pada daun caisim termasuk tinggi. Kadar air yang tinggi dapat mengundang banyak mikroorganisme maupun hama.Lubang daun disebabkan oleh hama yang hinggap pada daun caisim.Menurut Dharmaputra, dkk (1997), hama yang banyak menyerang tanaman caisim yaitu ulat tritip (Plutella maculipenis).

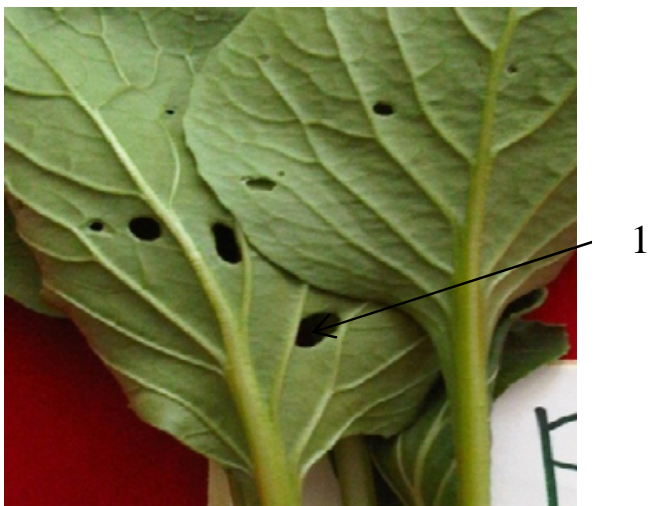

Keterangan:

1. Lubang Daun

Berdasarkan hasil analisis statistik uji $\mathrm{F}$ menunjukkan bahwa penambahan kombinasi pupuk organik hayati cair dan pupuk anorganik pada media tanah dan kompos tidak berpengaruh terhadap warna hijau daun caisim.

Tabel 4. Rerata warna daun yang diberi berbagai perlakuan pupuk organik hayati cair dan pupuk anorganik pada minggu ke -4 setelah tanam.

\begin{tabular}{|c|c|}
\hline \multirow[t]{2}{*}{ Perlakuan } & Warna daun \\
\hline & Kriteria daun \\
\hline $\begin{array}{l}\text { P0 (media dasar berupa tanah } \\
+ \text { kompos) }\end{array}$ & Hijau tua cerah \\
\hline P1 (media dasar+4,35 g NPK) & Hijau cerah \\
\hline $\begin{array}{l}\text { P2 (media dasar+2 mL } \\
\text { POHC }+4,35 \mathrm{~g} \text { NPK) }\end{array}$ & $\begin{array}{l}\text { Hijau tua agak } \\
\text { gelap }\end{array}$ \\
\hline $\begin{array}{l}\text { P3 (media dasar+2 mL } \\
\text { POHC }+2,17 \mathrm{~g} \mathrm{NPK})\end{array}$ & $\begin{array}{l}\text { Hijau cerah agak } \\
\text { muda }\end{array}$ \\
\hline $\begin{array}{l}\text { P4 (media dasar+2 mL } \\
\text { POHC }+1,07 \mathrm{~g} \mathrm{NPK})\end{array}$ & Hijau cerah \\
\hline $\begin{array}{l}\text { P5 (media dasar+1 mL POHC } \\
+4,35 \mathrm{~g} \text { NPK) }\end{array}$ & $\begin{array}{l}\text { Hijau cerah agak } \\
\text { muda }\end{array}$ \\
\hline $\begin{array}{l}\text { P6 (media dasar+1 mL } \\
\text { POHC+2,17 g NPK) }\end{array}$ & $\begin{array}{l}\text { Hijau tua agak } \\
\text { gelap }\end{array}$ \\
\hline $\begin{array}{l}\text { P7 (media dasar+1 mL } \\
\text { POHC+1,07 } \mathrm{g} \mathrm{NPK})\end{array}$ & $\begin{array}{l}\text { Hijau tua agak } \\
\text { gelap }\end{array}$ \\
\hline
\end{tabular}

Berdasarkan hasil pengukuran kromatisitas daun pada tanaman caisim yang ditanam pada media dengan penambahan pupuk organik hayati cair dan pupuk anorganik tidak menunjukkan 
adanya perbedaan, semua daun caisim berwarna hijau.

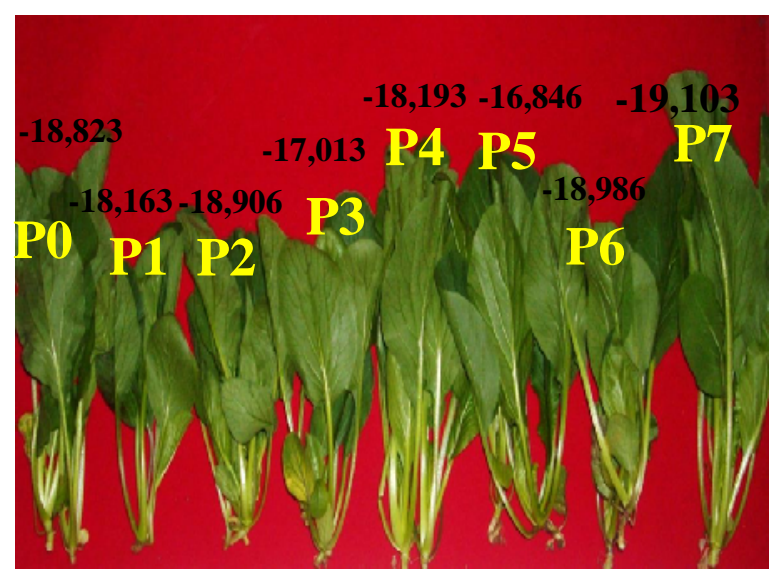

Gambar 1. Rerata warna daun caisim pada yang ditanam pada media dengan penambahan pupuk organik hayati cair dan pupuk anorganik pada minggu ke -4 setelah tanam

Berdasarkan nilai kromatisitas warna hijau menunjukkan bahwa penambahan $1 \mathrm{~mL}$ pupuk organik hayati cair dan 4,35 g NPK memberikan kecenderungan warna daun caisim yang hijau cerah agak muda, sedangkan penambahan $1 \mathrm{~mL}$ POHC dan 1,07 g NPK memiliki kecenderungan warna daun caisim hijau tua agak gelap. Penambahan pupuk organik hayati cair mengandung bakteri Pseudomonas dan Klebsiella yang menyebabkan warna daun menjadi lebih hijau. Hal ini diperkuat oleh pendapat James dan Olivares (1997), bahwa bakteriPseudomonas dan Klebsiella dapat menambat nitrogen atau $\mathrm{N}$ bebas dari udara sehingga dapat meningkatkan kandungan nitrogen di dalam daun.

Unsur hara yang diserap oleh akar ditranslokasikan ke bagian tanaman lainnya untuk proses metabolisme, terutama organ daun.Organ daun sangat penting bagi tanaman, sebab daun merupakan tempat terbentuknya hasil fotosintat.Nitrogen yang terkandung dalam tanaman berperan sebagai prekusor dalam pembentukan klorofil.Semakin banyak klorofil yang terkandung pada suatu daun maka semakin hijau daun tersebut.Hal ini sesuai pernyataan Higa dan Widiana (1991), bahwa tanaman yang diberi perlakuan pupuk organik hayati mempunyai jumlah klorofil yang lebih banyak sehingga memberikan warna daun yang lebih hijau.

Penambahan pupuk organik hayati cair dan pupuk anorganik tidak berpengaruh terhadap pengukuran luas penguningan daun hari ke-5 pascapanen.

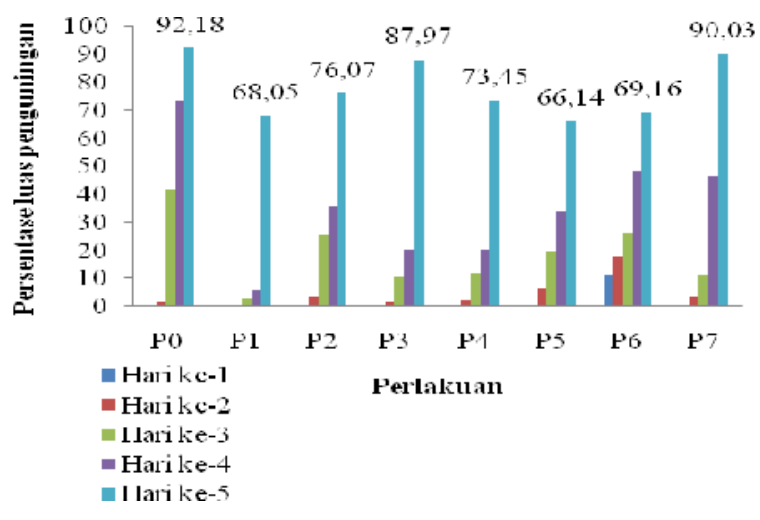

Gambar 2. Histogram luas penguningan daun pada hari ke-1 sampai hari ke-5

Penambahan pupuk organik hayati cair dan pupuk anorganik tidak berpengaruh terhadap luas penguningan daun pascapanen.Hal tersebut disebabkan banyak faktor lain yang mempengaruhi luas penguningan daun dibandingkan dengan penambahan berbagai perlakuan pupuk. Luas penguningan daun dihitung setelah panen sehingga proses fotosintesis tanaman caisim sudah terhenti.

Perubahan warna hijau menjadi warna kuning salah satunya disebabkan oleh cahaya. Proses fotosintesis berhenti dan pigmen hijau pada daun caisim akan berubah akibat pengaruh cahaya. Menurut Biswal dan Biswal (1984),cahaya dapat menghambat atau mempercepat degradasi klorofil pada tanaman yang masih melakukan proses metabolisme, karena pembentukan klorofil memerlukan cahaya matahari. Selain itu perubahan warna hijau daun disebabkan oleh kandungan klorofil yang mulai hilang dan digantikan dengan warna pigmen yang lainnya.Menurunnya kemampuan klorofil untuk mempertahankan warna hijau pada daun disebabkan karena disfungsi daun tersebut dalam menyerap cahaya untuk melakukan 
fotosintesis sehingga pigmen klorofil terdegradasi (Pantastico, 1989).

Menurut Kartasapoetra (1994), laju respirasi merupakan salah satu faktor yang menyebabkan penguningan daun. Semakin tinggi laju respirasi maka akan mempercepat terjadinya perombakanperombakan yang mengarah pada kerusakan, salah satunya perubahan hijau daun menjadi kuning. Proses respirasi yang tinggi akan mempercepat produksi etilen. Etilen dapat memacu terjadinya penuaan pada daun dan menyebabkan hilangnya klorofil dan memacu terbentuknya karotenoid (Salisbury dan Ros, 1995).

Beberapa enzim yang terlibat dalam degradasi klorofil yaitutahapan hidrolisis klorofil, pemindahan magnesium, modifikasi struktur cincin tetrapirol dan akhirnya memecah cincin.Enzim klorofilase dan $\mathrm{mg}$ dekhatalase memiliki fungsi spesifik yang berkaitan dengan metabolisme klorofil (Wartini, dkk., 2007).

Seiring dengan hal tersebut kloroplas mulai mengalami penuaan dan butir-butir pati telah menghilang.Terjadi pembongkaran dan pelarutan pada daerah stroma kemudian grana mulai menghilang. Seiring dengan itu terjadi pembentukan kromoplas dan pigmen yang lain. Bagian kromoplas terdapat karotenoid dan pigmen-pigmen lain seperti xantofil, antosianin.Apabila klorofil terdegradasi maka akan terjadi perubahan warna yang didominasi oleh warna xantofil dan karotenoid (Pantastico, 1989).

\section{KESIMPULAN}

Penambahan pupuk organik hayati cair dan pupuk anorganik pada media tanam tidak berpengaruh terhadap kadar air dan penampakan fisik namun berpengaruh terhadap kadar serat daun. Penambahan $1 \mathrm{ml}$ pupuk organik hayati cair dan 2,17 g NPK pada media tanam dapat meningkatkan kadar serat daun caisim (Brassica juncea L.) varietas Tosakan.

\section{DAFTAR PUSTAKA}

Biswal, U. C., and B. Biswal. 1984. Photocontrol of leafsenescence. Photochem.Photobiol. 39: 875-879.

East West Seed. 2006. Deskripsi Beberapa Varietas Caisim. PT. East West Seed, Indonesia.
Elviera, D. 1995. Deskripsi Fungi Penyebab Penyakit Bercak Daun pada Anakan Pulai(Alstonia pneumatophoraBack.) .[Skripsi]. Jawa Barat.Institut Pertanian Bogor.

Fajriani, A. 2011.Penambahan Pupuk Organik Hayati Cair dan Pupuk Anorganik pada Media Tanam Terhadap Pertumbuhan dan Produktivitas Tanaman Caisim (Brassica juncea L.).[Skripsi].Semarang.Universitas Diponegoro.

Fransisca, S. 2009. Respon Pertumbuhan dan Produksi Sawi (Brassica juncea L.)Terhadap Penggunaan Pupuk Kascing dan Pupuk Organik Cair.[Skripsi]. Medan.Universitas Sumatra Utara.

Gardner, P.F, Pearce, R.B, Mitchell, R. 1991. Fisiologi Tanaman Budidaya. Penerbit Universitas Indonesia. Jakarta

Hanafiah, A. K. 2004. Dasar-Dasar Ilmu Tanah.PT. Raja Grafindo Persada. Jakarta

Higa, T. dan Wididana, G.N. 1993.Peranan Effecive Mikroorganism dalam Meningkatkan Kesuburan dan Produktivitas Tanah.[Skripsi].Jawa Barat. Institut Pertanian Bogor.

James E. and Olivares F. L. 1997.Infection and Colonization of Sugarcane and other Graminaceous Plant by Endophitic Diazotrophicus.IRRI.Jepang.

Kartasapoetra, A. G. 1994. Teknologi Penanganan Pasca Panen. Penerbit Rineka Cipta. Jakarta.

Margiyanto, E. 2008.Budidaya Tanaman Sawi. http://Zuldesains.wordpress.com.10 Januari 2010.

Martynuk, S. and Wagner G. W. 1978.Quantitative and Qualitative Examination of Soil Microflora Associate.Management System Soil Sci (2): 345-350.

Nirwana, A.C. 2009.Faktor Kimia yang Mempengaruhi Kualitas Produk Holtikultura.http:// www.Usaha mandiri.co.id. 29 April 2011.

Pantastico. 1989. Fisiologi Pasca Panen.Gadjah Mada University Press, Yogyakarta.

Razak, N., Arafah, dan Sirrapa, M.P. 2005.Kajian Penggunaan Pupuk Organik dengan Berbagai Dosis Pupuk Anorganik Terhadap 
Pertumbuhan dan Hasil Padi Varietas Gilirang di Lahan Sawah Irigasi.Jurnal Agrivigor. 5(1): 46-54.

Rukmana, R. 2007. Bertanam Petsai dan Sawi.Penerbit Kanisius. Yogyakarta.

Setyamidjaja, D. 1986. Pupuk dan Pemupukan. CV. Simplex. Jakarta.
Utami, E. 2010.Pengaruh Subtitusi Rumput Gajah dengan Limbah Tanaman Sawi Putih Fermentasi Terhadap Penampilan Produksi Domba Lokal Jantan Ekor Tipis. [Skripsi]. Universitas Diponegoro. Semarang.

Winarno, F. G. 2002. Fisiologi Lepas Panen Produk Holtikultura. M- Brio Press. Bogor. 